\title{
Use of os calcis quantitative ultrasound for bone mineral density screening in adolescents with menstrual dysfunction
}
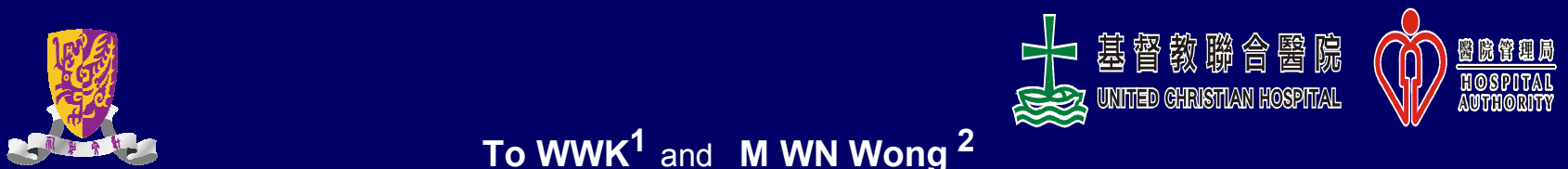

\section{To WWK $^{1}$ and $\mathbf{M}$ WN Wong 2}

1 Department of Obstetrics \& Gynaecology, United Christian Hospital

2 Department of Orthopaedics \& Traumatology, The Chinese University of Hong Kong, Hong Kong

\section{Background}

Bone mineral density (BMD) in young females is related to exercise, body mass index, body composition and menstrual status. Prolonged hypothalamic amenorrhoea with anovulation has been associated with hypo-oestrogenism in adolescents and has been shown to be associated with lower bone mineral density (BMD) values compared to eumenorrheic adolescents of similar age using standard dual energy $X$-ray absorptiometry (DXA) measurements.

\section{Objective}

To determine whether differences in BMD between oligo/amenorrhoeic adolescents at risk of low BMD and normal eumenorrhoeic controls can be detectable by quantitative ultrasound (QUS) of the os calcis or by peripheral quantitative computerized tomography (PQCT) of the distal tibia

\section{Methods}

Adolescents with oligo/amenorrhoea (defined as having amenorrhoea for $\mathbf{3}$ months or more in past 1 year) and a control group of eumenorrhoeic adolescents of similar age were recruited from the Adolescent Gynaecology clinic. All underwent basic anthropometric measurements, body fat composition estimation using bio-electrical impedance methods, hormonal profile assay. All subjects also underwent DXA of the lumbar spine and hip, peripheral quantitative computerized tomography (pQCT) measurement of distal radius/ tibia volumetric BMD, as well as QUS of the os calcis. All subjects in the study group also had pelvic ultrasound to exclude polycystic ovaries. Those on regular oestrogen treatment for over 3 months in the past 1 year were excluded from the study. Written consent was obtained from all subjects or their parents.

\section{Results}

A total of $\mathbf{4 5}$ eumenorrhoeic (EU group) and $\mathbf{3 0}$ oligo/amenorrhoeic adolescents (OA group) aged 15 to 19 (mean age 16.8) were recruited. There were no significant differences in the height, body mass index or body fat percentage of the two groups.
Table 1. Comparing BMD values of oligo/ amenorrheic and eumenorrhoeic adolescents

\begin{tabular}{|c|c|c|c|c|}
\hline & $\begin{array}{l}\text { OA } \\
\text { group } \\
\mathrm{N}=26 \\
\text { (SD) }\end{array}$ & $\begin{array}{l}\text { EU } \\
\text { group } \\
\mathrm{N}=14 \\
\text { (SD) }\end{array}$ & $\begin{array}{l}p- \\
\text { value }\end{array}$ & $\begin{array}{l}\text { Mean } \\
\text { difference } \\
(95 \% \mathrm{Cl})\end{array}$ \\
\hline $\begin{array}{l}\text { Lumbar spine } \\
\text { L2-L4 (mg/cm²) }\end{array}$ & $\begin{array}{c}0.88 \\
(0.094)\end{array}$ & $\begin{array}{l}0.964 \\
(0.12)\end{array}$ & 0.002 & $\begin{array}{l}-0.082 \\
(-0.13 \text { to }-0.03)\end{array}$ \\
\hline $\begin{array}{l}\text { Mean neck of } \\
\text { femur }\left(\mathrm{mg} / \mathrm{cm}^{2}\right)\end{array}$ & $\begin{array}{c}0.821 \\
(0.092)\end{array}$ & $\begin{array}{c}0.867 \\
(0.099)\end{array}$ & 0.05 & $\begin{array}{l}-0.04 \\
(-0.091 \text { to- } 0.001)\end{array}$ \\
\hline $\begin{array}{l}\text { Mean Ward's } \\
\text { triangle }\left(\mathrm{mg} / \mathrm{cm}^{2}\right)\end{array}$ & $\begin{array}{c}0.686 \\
(0.099) \\
\end{array}$ & $\begin{array}{c}0.754 \\
(0.114) \\
\end{array}$ & 0.01 & $\begin{array}{l}-0.067 \\
(-0.11 \text { to- }-0.017)\end{array}$ \\
\hline $\begin{array}{l}\text { Mean Trochanter } \\
\left(\mathrm{mg} / \mathrm{cm}^{2}\right)\end{array}$ & $\begin{array}{c}0.655 \\
(0.073)\end{array}$ & $\begin{array}{c}0.713 \\
(0.097)\end{array}$ & 0.007 & $\begin{array}{l}-0.058 \\
(-0.09 \text { to- } 0.016)\end{array}$ \\
\hline $\begin{array}{l}\text { Mean tibia (core) } \\
\left(\mathrm{mg} / \mathrm{cm}^{3}\right)\end{array}$ & $\begin{array}{l}278 \\
(29) \\
\end{array}$ & $\begin{array}{l}294 \\
(53) \\
\end{array}$ & 0.13 & $\begin{array}{l}-16 \\
(-37 \text { to } 5)\end{array}$ \\
\hline $\begin{array}{l}\text { Mean tibia } \\
(\text { Total })\left(\mathrm{mg} / \mathrm{cm}^{3}\right)\end{array}$ & $\begin{array}{l}550 \\
(69)\end{array}$ & $\begin{array}{l}510 \\
(61)\end{array}$ & 0.014 & $\begin{array}{l}-39 \\
(-70 \text { to }-8.4)\end{array}$ \\
\hline $\begin{array}{l}\text { QUS os calcis } \\
\text { BMD }\end{array}$ & $\begin{array}{c}0.49 \\
(0.07)\end{array}$ & $\begin{array}{l}0.58 \\
(0.08)\end{array}$ & 0.035 & $\begin{array}{l}-0.09 \\
(-0.18 \text { to }-0.006)\end{array}$ \\
\hline QUS Stiffness & $\begin{array}{c}96 \\
(14)\end{array}$ & $\begin{array}{l}103 \\
(15)\end{array}$ & 0.04 & $\begin{array}{l}-7.3 \\
(-14 \text { to }-0.21)\end{array}$ \\
\hline
\end{tabular}

The oligo/amenorrhoeic group had demonstrably lower BMD at the lumber spine $(0.88 \mathrm{Vs} 0.96 \mathrm{~g} / \mathrm{cm} 2$, $p=0.002$ ) and hip sites (neck of femur 0.82 Vs 0.86 $\mathrm{g} / \mathrm{cm} 2, \mathrm{p}=0.05$; trochanter $0.65 \mathrm{Vs} 0.71 \mathrm{~g} / \mathrm{cm} 2, \mathrm{p}$ $=0.007$; Ward's triangle $0.68 \mathrm{Vs} 0.75 \mathrm{~g} / \mathrm{cm} 2, \mathrm{p}=0.01$ ). PQCT showed the oligo/amenorrheic group had lower total BMD in the distal tibia (510 Vs 550 $\mathrm{mg} / \mathrm{cm} 3 ; p=0.014)$. QUS measurements showed that the oligo/ amenorrhoeic group also had lower stiffness values ( 96 Vs 103, $p=0.035$ ) and lower derived BMD values $(0.49 \mathrm{Vs} 0.58 \mathrm{~g} / \mathrm{cm} 2 ; p=0.04)$.

\section{Conclusion}

In a high risk group of adolescents with menstrual dysfunction, the significantly lower BMD values in the axial and appendicular sites as demonstrated by DXA and PQCT were also reflected in lower estimated BMD values in QUS measurements. The findings supported the use of quantitative USG as a screening tool for low BMD in high risk adolescents. 